\title{
Potensi Krim Ekstrak Daun Johar (Cassia siame) Menghambat Pertumbuhan Candida albicans
}

\section{Potention of Johar's Leaf Extract (Cassia siame) Cream to Inhibit Candida albicans Growth}

\author{
Andi Tenriugi Daeng Pine, Arief Azis, Ika Riski Darmawan
}

\author{
Akademi Farmasi Yamasi Makassar \\ Jalan Mapala II Blok D5 No. 10 Makassar \\ Sur-el : pinefarma@gmail.com
}

\begin{abstract}
Abstrak
Penelitian ini bertujuan untuk mengetahui potensi krim ekstrak daun johar untuk menghambat pertumbuhan Candida albicans. Penelitian ini merupakan penelitian ekperimental. Daun johar (Cassia siamea Lamk.) diekstraksi dengan metode maserasi mengunakan pelarut etanol $96 \%$ kemudian diformulasi dalam bentuk sediaan krim dengan konsentrasi ekstrak 5\%b/b dan 10\%b/b. Sediaan krim tersebut kemudian diuji kemampuan daya hambatnya terhadap pertumbuhan Candida albicans dengan metode sumuran. Hasil penelitian menunjukkan krim ekstrak daun johar (Cassia siamea Lamk.) konsentrasi 10\%b/b memiliki diameter zona hambat terhadap pertumbuhan Candida albicans sebesar 22,5 mm. Daya hambat dari krim ekstrak daun johar konsentrasi $10 \%$ b/b termasuk kategori sangat kuat.
\end{abstract}

Kata kunci : Ekstrak daun johar (Cassia siamea Lamk.), krim, Candida albicans, uji daya hambat

\begin{abstract}
This aims studies to determine the potential of johar leaf extract cream to inhibit Candida albicans growth. This research is an experimental research. Johar leaves (Cassia siamea Lamk.) was extracted by maceration method using ethanol $96 \%$ then formulated into dosage forms cream with concentrations of extract $5 \% \mathrm{w} / \mathrm{w}$ and $10 \% \mathrm{w} / \mathrm{w}$. The cream were preparations then tested the ability of inhibitory Candida albicans growth by the wells method. The results showed johar leaf extract (Cassia siamea Lamk.) cream 10\% w/w has a diameter of inhibition zone against the growth of Candida albicans by $22.5 \mathrm{~mm}$. Inhibition of leaf extracts johar cream $10 \% \mathrm{w} / \mathrm{w}$ including a very strong category.
\end{abstract}

Keywords: johar's leaf extract, cream, inhibition, Candida albicans

\section{PENDAHULUAN}

Obat tradisional merupakan salah satu warisan budaya bangsa Indonesia yang telah digunakan selama berabad-abad untuk pencegahan, pengobatan, dan pemeliharaan kesehatan. Berbagai macam tumbuhan yang mengandung berbagai jenis senyawa kimia alami telah digunakan penduduk Indonesia sebagai pengobatan tradisional.

Johar (Cassia siamea Lamk.) merupakan salah satu tumbuhan dengan batang pohon yang keras. Daunnya mengandung senyawa alkaloida, saponin, flavonoid, dan tannin. Secara empiris, masyarakat menggunakan daun johar sebagai obat gatal-gatal. Selain itu, daun johar juga dimanfaatkan sebagai obat diabetes, antimalaria, penyembuhan luka, dan sebagai tonik karena kandungan flavonoid dan karotenoidnya yang tinggi (Kusmardi, Kumala, S., Dwitia, 2006)

Penggunaan daun johar sebagai obat gatalgatal biasanya dilakukan dengan cara 
mengoleskan air rebusan daun johar pada daerah kulit yang gatal atau digunakan sebagai air mandi. Penggunaan dengan cara tersebut mempunyai beberapa kekurangan. Salah satu di antaranya yaitu sediaan rebusan harus selalu dibuat segar, tidak dapat disimpan dalam jangka waktu yang lama, dan tidak praktis dibawa kemana-mana.

Agar penggunaan daun johar sebagai obat tradisional menjadi lebih efisien, praktis, dan dapat meningkatkan nilai ekonomisnya maka diperlukan modifikasi bentuk sediaan. Salah satu bentuk sediaan untuk kulit yang sering digunakan adalah sediaan berbentuk krim.

Krim adalah bentuk sediaan setengah padat berupa emulsi yang mengandung satu atau lebih bahan obat terlarut atau terdispersi ke dalam bahan dasar yang sesuai (mengandung air tidak kurang dari 60\%). Istilah ini telah digunakan untuk sediaan setengah padat yang mempunyai konsistensi relatif cair yang diformulasi sebagai emulsi air dalam minyak (A/M) atau minyak dalam air (M/A) (Syamsuni, 2012)

Menurut penelitian yang telah dilakukan oleh Aan Risma (1994), infus daun johar mempunyai aktivitas antimikroba terhadap beberapa bakeri dan jamur penyebab penyakit kulit (Indriyani \& Wulandari, 2015)

Candida albicans adalah spesies cendawan patogen dari golongan Deuteromycota. Spesies cendawan ini merupakan penyebab infeksi oportunistik yang disebut kandidiasis pada kulit, mukosa, dan organ dalam manusia. Candida albicans dapat menjadi dominan dan menyebabkan keadaan-keadaan patologi ketika daya hambat tubuh menurun baik secara lokal maupun sistemik. Kadang-kadang Candida albicans menyebabkan penyakit sistemik progresif pada penderita yang lemah atau sistem imunnya menurun (Simatupang, Magdalena, 2009)

Penelitian ini bertujuan untuk mengetahui potensi krim ekstrak daun johar dalam menghambat pertumbuhan Candida albicans dengan menggunakan metode sumuran.

Hasil dari penelitian ini diharapkan dapat memberikan informasi produk baru yang bermanfaat bagi masyarakat khususnya produk krim ekstrak daun johar sebagai obat candidiasis.

\section{METODE PENELITIAN}

\section{Alat dan Bahan yang digunakan}

Alat yang digunakan adalah rotavapor (Merck), penangas air (Memmert), jangka sorong, cawan petri (Pyrex), Laminar Air Flow (Memmert), oven (Memmert), autoklaf (Memmert), dan timbangan analitik (O'hauss).

Bahan yang digunakan adalah ekstrak daun johar, ssam stearat, gliserin, natrium tetraboras, nipagin, trietanolamin, air suling, kapas, kertas pH, pencadang, etanol 96\%, medium Potato Dextrosa Agar (PDA), biakan murni jamur Candida albicans.

\section{Penyiapan sampel}

Bahan uji Daun Johar diambil dari Pohon Johar yang berada di lingkungan Akademi Farmasi Yamasi Makassar. Daun lalu dicuci 
bersih dibawah air mengalir, lalu sampel tersebut dikeringkan, dan ditimbang sebanyak 300 gram yang dibutuhkan untuk proses ekstraksi.

\section{Pembuatan Ekstrak Daun Johar}

Metode ekstraksi yang digunakan adalah metode maserasi. Sebanyak 300 gram sampel ditimbang seksama, dimasukkan dalam labu maserasi lalu dibasahkan dengan pelarut etanol 96\%, kemudian ditambahkan lagi pelarut etanol $96 \%$ sampai sampel terendam seluruhnya. Ekstraksi dilakukan selama tiga hari di tempat yang terlindung dari cahaya sambil sesekali diaduk. Setelah tiga hari, ekstrak daun johar disaring ke dalam wadah dan ampasnya diekstraksi kembali dengan pelarut etanol 96\%. Ekstrak yang diperoleh dikumpulkan dan kemudian dipekatkan menggunakan rotavapor hingga diperoleh ekstrak kental. Ekstrak kental dikeringkan di atas penangas sampai diperoleh ekstrak kental.

\section{Pembuatan Krim Ekstrak Daun Johar}

Pembuatan krim dilakukan dengan membuat 2 formula krim dengan konsentrasi ekstrak daun johar yang berbeda dengan basis yang sama. Masing-masing krim mengandung ekstrak daun johar sebesar 5\% b/b dan $10 \% \mathrm{~b} / \mathrm{b}$ dengan komposisi basis dan metode pembuatan krim yang sama.

\section{Penyiapan dan pengujian daya hambat mikroba uji}

\section{Pembuatan Supensi Mikroba Uji}

Pembuatan suspensi jamur uji dilakukan dengan mengambil satu ose jamur Candida albicans dan dimasukkan ke dalam tabung reaksi yang berisi $\mathrm{NaCl} 0,9 \%$ sebanyak $3 \mathrm{ml}$, kemudian dicampur hingga homogen ditandai dengan cairan berubah menjadi keruh sesuai standar kekeruhan Mc Farland 0,5. Penghitungan mikroba dengan Standard McFarland adalah dengan penyetaraan konsentrasi mikroba dengan menggunakan larutan $\mathrm{BaCl}_{2} \quad 1 \%$ dan $\mathrm{H}_{2} \mathrm{SO}_{4} \quad 1 \%$. Standar kekeruhan Mc Farland ini dimaksudkan untuk menggantikan perhitungan mikroba satu per satu dan untuk memperkirakan kepadatan sel yang akan digunakan pada prosedur pengujian antimikroba.

Tabel 1. Formula krim esktrak daun johar

\begin{tabular}{llcccl}
\hline \multirow{2}{*}{ No } & Nama Bahan & \multicolumn{5}{c}{$\begin{array}{c}\text { Formula } \\
\% \text { b/b }\end{array}$} & Fungsi \\
\cline { 3 - 6 } & Ekstrak Daun Johar & 5 & B $(10 \%)$ & C (kontrol) & \\
\hline 1 & Asam Stearat & 19 & 10 & 0 & Zat Aktif \\
\hline 2 & 13 & 13 & 19 & Pengemulsi \\
\hline 3 & Gliserin & 0,3 & 0,3 & 0,3 & Pelembut \\
\hline 4 & NatriumTetraboras & 1,3 & 1,3 & 1,3 & Pengemulsi \\
\hline 5 & Trietanolamin & 0,15 & 0,15 & 0,15 & Pengawet \\
\hline 6 & Nipagin & hingga 100 & hingga 100 & hingga 100 & Pelarut \\
\hline 7 & Aqua destillata & & & & \\
\hline
\end{tabular}




\section{Peremajaan Mikroba Uji}

Mikroba uji yaitu Candida albicans, diambil satu ose dari biakan murni kemudian diinokulasikan pada medium PDA miring, setiap pekerjaan laboratorium dilakukan di dekat api Bunsen guna menjaga sterilisasinya. Setelah itu cawan petri dimasukkan ke dalam inkubator selama 3 kali 24 jam dengan suhu $37^{\circ} \mathrm{C}$ untuk menumbuhkan mikroba yang diuji.

\section{Pengujian Daya Hambat}

Medium PDA dituang dan ditambahkan dengan suspensi jamur uji ke dalam cawan petri steril sebanyak $20 \mathrm{ml}$, kemudian dihomogenkan dan didiamkan hingga memadat. Dibuat lubang sumuran pada medium PDA menggunakan pencadang. Kemudian ditimbang bobot krim dengan konsentrasi $5 \% \mathrm{~b} / \mathrm{b}$ sebanyak $0,23 \mathrm{~g}$, konsentrasi $10 \% \mathrm{~b} / \mathrm{b}$ sebanyak $0,23 \mathrm{~g}$, basis krim (kontrol negatif) sebanyak 0,23g. Lalu masukkan ke dalam medium. Selanjutnya diinkubasi pada suhu $37^{\circ} \mathrm{C}$ selama 3 kali 24 jam. Uji daya hambat jamur ditentukan dengan mengukur diameter zona hambat yang pengujiannya dilakukan tiga kali pengulangan (triplo).

Pengamatan dan Pengukuran Diameter

\section{Hambatan}

Pengamatan dan pengukuran diameter hambatan dilakukan dengan menggunakan jangka sorong setelah diinkubasikan selama 3 kali 24 jam.

\section{HASIL DAN PEMBAHASAN}

Penelitian ini dilakukan untuk menguji daya hambat krim ekstrak daun johar terhadap Candida albicans secara in vitro dengan cara memberikan suatu zat tertentu dengan menggunakan metode sumuran. Ketika jamur diberikan zat tertentu, maka pertumbuhannya akan terhambat sehingga disebut sebagai antimikroba atau antijamur. Terhambatnya

Tabel 2. Klasifikasi Respon Hambatan Pertumbuhan Jamur (Alfiah, Khotimah, \& Turnip, 2015)

\begin{tabular}{cc}
\hline Diameter Zona Bening & Respon Hambatan Pertumbuhan Jamur \\
\hline$>20 \mathrm{~mm}$ & Sangat kuat \\
$11-20 \mathrm{~mm}$ & Kuat \\
$6-10 \mathrm{~mm}$ & Sedang \\
$\leq 5 \mathrm{~mm}$ & Lemah \\
\hline
\end{tabular}

Tabel 3. Hasil Pengukuran Diameter Zona Hambatan

\begin{tabular}{cccc}
\hline \multirow{2}{*}{ Replikasi } & \multicolumn{3}{c}{$\begin{array}{c}\text { Diameter Zona Hambat } \\
(\mathrm{mm})\end{array}$} \\
\cline { 2 - 4 } & $\begin{array}{c}\text { Krim dengan } \\
\text { ekstrak 5\%b/b }\end{array}$ & $\begin{array}{c}\text { Krim dengan } \\
\text { ekstrak 10\%b/b }\end{array}$ & Basis krim tanpa ekstrak \\
\hline I & 18 & 22 & - \\
\hline II & 21 & 23 & - \\
\hline III & - & - & - \\
\hline Rata-rata & 19,5 & 22,5 & - \\
\hline Kategori & Kuat & Sangat kuat & - \\
\hline
\end{tabular}


pertumbuhan jamur Candida albicans dapat dilihat dengan terbentuknya zona hambat. Zona hambat adalah zona bening yang terdapat di sekitar lubang sumuran pada medium yang telah diinokulasi jamur Candida albicans atau zona yang tidak terdapat pertumbuhan Candida albicans (Jawets, Melnick, \& Adelberg, 2015). Diameter zona hambat merupakan petunjuk kepekaan jamur uji. Semakin luas zona hambat maka krim ekstrak daun johar mempunyai daya antijamur yang semakin baik.

Data yang diperoleh pada penelitian ini adalah krim ekstrak daun johar dengan konsentrasi $5 \%$ b/v sudah dapat menghambat pertumbuhan jamur dengan rata-rata diameter zona hambatnya yaitu $19,5 \mathrm{~mm}$. Hal tersebut terjadi pula pada krim yang menggunakan konsentrasi ekstrak daun johar sebanyak $10 \%$ b/v yang menunjukkan daerah zona hambat yang lebih luas dengan rata-rata diameter zona hambat yaitu $22,5 \mathrm{~mm}$, sedangkan pada basis krim yang digunakan sebagai kontrol negatif dan tidak mengandung ekstrak daun johar menunjukkan tidak adanya daerah zona hambatan terhadap pertumbuhan Candida albicans sebagaimana terlihat pada gambar di bawah ini.

Mekanisme penghambatan pertumbuhan Candida albicans diawali oleh adanya senyawa kimia pada daun johar. Senyawasenyawa tersebut antara lain alkaloid, flavonoid, saponin, tannin, fenol, antrakuinon, antosianin, dan glikosida jantung. (Ningrum, Widia, Kusrini, \& Fachriyah, 2017) Senyawa kimia tersebut ada yang dapat merusak struktur dinding sel pada Candida albicans. Dinding sel Candida albicans tersusun atas mannoproteins dan kitin. Senyawa kimia yang dapat merusak dinding sel Candida albicans tersebut diantaranya adalah senyawa tannin dan flavonoid.

Peranan senyawa flavonoid sebagai antifungi yaitu dapat berperan langsung dalam menghambat pertumbuhan fungi dengan cara membentuk kompleks dengan protein
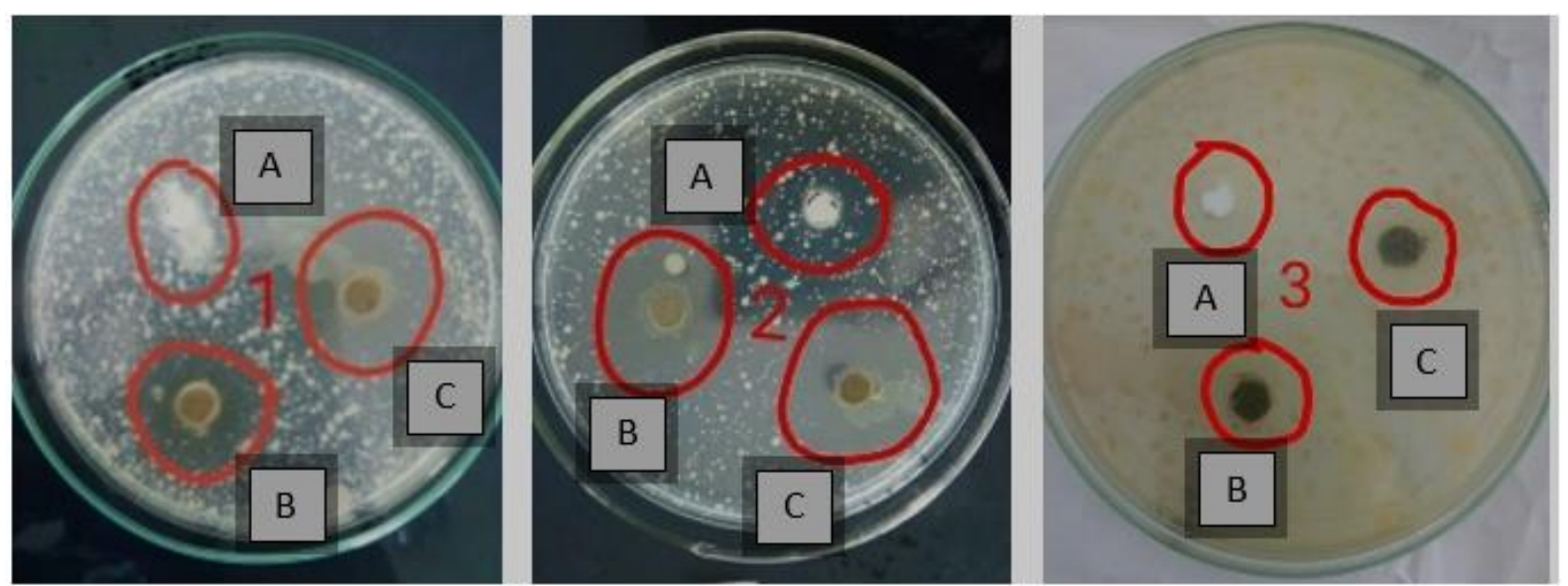

Gambar 1. Zona hambat krim ekstrak daun johar dengan konsentrasi 5\% b/b, $10 \%$ b/b dan basis krim tanpa ekstrak terhadap Candida albicans yang direplikasikan tiga kali

Keterangan:

A: basis krim tanpa ekstrak

B: krim ekstrak daun johar konsentrasi 5\%b/b

C: krim ekstrak daun johar konsentrasi $10 \% \mathrm{~b} / \mathrm{b}$ 
membran dan merusak membran sel dengan cara mendenaturasi ikatan protein pada membran sel, sehingga membran sel menjadi lisis dan senyawa tersebut menembus kedalam inti sel yang menyebabkan fungi tidak berkembang (Hartini, 2017)

Menurut (Harborne, 1996) tanin merupakan senyawa polifenol yang dapat mengendapkan protein penyusun dinding sel. Jika terjadi pengendapan protein pada dinding sel maka akan mengakibatkan terjadinya kerusakan. Dengan rusaknya dinding sel tersebut, memudahkan masuknya substansi yang tidak diinginkan kedalam sel. Setelah dinding sel rusak, senyawa flavonoid masuk ke dalam membran plasma dan merusak membran plasma pada jamur.

Senyawa fenol mampu memutuskan ikatan peptidoglikan dalam usahanya menerobos dinding sel. Mekanisme senyawa fenol sebagai zat antimikroba adalah dengan cara meracuni protoplasma, merusak dan menembus dinding sel, serta mengendapkan protein sel mikroba. Senyawa fenolik bermolekul besar mampu menginaktifkan enzim esensial didalam sel mikroba meskipun pada konsentrasi yang sangat rendah (Lely, N., Triwidodo, J., 2017).

Candida albicans merupakan salah satu jamur yang dapat menyebabkan berbagai penyakit salah satunya penyakit infeksi pada mulut seperti sariawan. Semakin besar konsentrasi ekstrak daun johar (Cassia siamea Lamk.) yang ditambahkan maka semakin besar pula zona hambatan yang terbentuk.

\section{KESIMPULAN}

Berdasarkan hasil penelitian maka dapat disimpulkan bahwa krim ekstrak daun johar konsentrasi 10\%b/b memiliki kemampuan menghambat pertumbuhan jamur Candida albicans dengan diameter zona hambat yang terbentuk sebesar $22,5 \mathrm{~mm}$ tergolong dalam kategori zona hambat yang sangat kuat.

\section{DAFTAR PUSTAKA}

Alfiah, R. R., Khotimah, S., \& Turnip, M. (2015). Efektivitas Ekstrak Metanol Daun Sembung ( Mikania micrantha Kunth ) Terhadap Pertumbuhan Jamur Candida albicans. Protobiont, 4(1), 52-57. Retrieved from http://jurnal.untan.ac.id/index.php/jprb/arti cle/viewFile/8735/8710

Harborne, J. B. (1996). Metode Fitokimia (2nd ed.). Bandung: ITB Press.

Hartini. (2017). Uji Aktivitas Antifungi Ekstrak Sarang Lebah dari Luwu Utara terhadap Candida Albicans Test of Antifungal Activity of Hive Extract and North Luwu Forest Honey on Candida albicans. BIOEDUKASI, 10(2), 44-46.

Indriyani, T., \& Wulandari, Y. (2015). IbM Pengolahan Daun Johar. Seminar Nasional Sains Dn Teknologi Terapan III, 361-368. Retrieved from http://jurnal.itats.ac.id/wpcontent/uploads/2015/10/11.TUTUK2_IbM_edited.pdf

Jawets, E., Melnick, J. L., \& Adelberg, E. A. (2015). Mikrobiologi Kedokteran. Jakarta: Salemba Medika.

Kusmardi, Kumala, S., Dwitia, W. (2006). Pengaruh Pemberian Ekstrak Etanol Daun Johar ( Cassia siamea Lamk .) Terhadap Peningkatan Aktivitas Dan Kapasitas Fagositosis Sel Makrofag. Makara, Kesehatan, 10(2), 89-93. 
Lely, N., Triwidodo, J., S. E. R. (2017). Uji Aktivitas Antimikroba Ekstrak Daun Wungu (Graptophyllum pictum L.Griff) Dengan Metode Bioautograf. Jurnal Ilmiah Bakti Farmasi, II(1), 49-56.

Ningrum, Widia, D., Kusrini, D., \& Fachriyah, E. (2017). Uji Aktivitas Antioksidan Senyawa Flavonoid dari Ekstrak Etanol Daun Johar (Senna siamea Lamk). Jurnal Kimia Sains Dan Aplikasi, 20(3), 123-129. Retrieved from https://media.neliti.com/media/publication s/230596-uji-aktivitas-antioksidansenyawa-flavon-bff512c5.pdf

Simatupang, Magdalena, M. (2009). CANDIDA ALBICANS. Retrieved from http://repository.usu.ac.id/bitstream/handle /123456789/1935/09E01452.pdf;jsessionid $=4 \mathrm{CF} 05889 \mathrm{AA} 30629 \mathrm{C} 560 \mathrm{~F} 2 \mathrm{D} 1748 \mathrm{FB} 5 \mathrm{~F}$ 75 ? sequence $=1$

Syamsuni. (2012). Farmasetika. Jakarta: EGC. 